\title{
A COMPARISON OF SOLID-PHASE EXTRACTION METHODS FOR BISPHENOL A IN CHEESE SAMPLES
}

\author{
Cemil Kürekci ${ }^{1}$, Sait Tan ${ }^{2}$, Ali Arslan ${ }^{3}$, Sara Betül Özgen ${ }^{4}$, Fatih Sakin ${ }^{5}$ \\ ${ }^{1}$ Department of Food Science and Technology, Faculty of Veterinary Medicine, Hatay Mustafa Kemal \\ University, Hatay, Turkey \\ ${ }^{2}$ Graduate School of Health Sciences, Firat University, Elazig, Turkey \\ ${ }^{3}$ Department of Food Science and Technology, Faculty of Veterinary Medicine, Firat University, Elazig, Turkey \\ ${ }^{4}$ Research and Application Center for Technology, Research and Development, Hatay Mustafa Kemal \\ University, Hatay, Turkey \\ ${ }^{5}$ Department of Pharmacology and Toxicology, Faculty of Veterinary Medicine, Hatay Mustafa Kemal \\ University, Hatay, Turkey
}

Received /Geliş: 22.02.2021; Accepted / Kabul: 06.05.2021; Published online / Online bask1: 24.05.2021

Kürekci, C., Tan, S., Arslan, A., Özgen, S.B., Sakin, F. (2021). A comparison of solid-phase extraction methods for bisphenol $a$ in cheese samples. GID A (2021) 46 (4) 848-858 doi: 10.15237/gida.GD21039

Kürekci, C., Tan, S., Arslan, A., Özgen, S.B., Sakin, F. (2021). Peynir numunelerinde bisfenol a için katı faz ekstraksiyon metotlarının karșılaştırılması. GIDA (2021) 46 (4) 848-858 doi: 10.15237/gida.GD21039

\begin{abstract}
In this study, four different solid phase extraction (SPE) methods were compared for the determination of bisphenol A (BPA) in cheese samples using HPLC-FD. All methods were validated according to the parameters; linearity, recovery, precision, detection and quantification limits (LOD-LOQ). Subsequently, BPA levels were determined in twenty cheese samples commercially available in Elazığ province. All the extraction methods showed good performances for quantitative analysis of PBA, achieving very low LOD $(0.16-0.39 \mu \mathrm{g} / \mathrm{kg})$ and LOQ $(0.53-1.30 \mu \mathrm{g} / \mathrm{kg})$ values. The average fortification recoveries for spiked BPA (3-30 $\mu \mathrm{g} / \mathrm{kg})$ ranged between 93.1 and $100.8 \%$. 55\% of cheese samples had BPA concentration ranging from $0.75 \mu \mathrm{g} / \mathrm{kg}$ to $8.46 \mu \mathrm{g} / \mathrm{kg}$ and estimated daily intake (EDI) was measured as $0,001 \mu \mathrm{g} / \mathrm{kg} \mathrm{BW}$ per day. On the basis of EDI, the consumption of cheese itself cannot be considered as significant health problem, but results impose a systematic monitoring of dairy products.

Keywords: Solid-phase extraction, Bisphenol A, cheese, HPLC

\section{PEYNİR NUMUNELERİNDE BİSFENOL A İÇİN KATI FAZ EKSTRAKSIYYON METOTLARININ KARŞILAŞTIRILMASI}

\section{ÖZ}

Bu çalışmada, dört farklı katı-faz ekstraksiyon metotunun peynir numunelerinden bisfenol A (BPA) ekstraksiyon performansı HPLC-FD kullanılarak kıyaslanmıştır. Metot validasyonları doğrusallık, geri kazanım, kesinlik, metodun belirlenme ve tayin alt sınırları (LOD/LOQ), bağıl standart belirsizlik

\footnotetext{
*Corresponding author / Yazışmalardan sorumlu yazar

$凶$ ckurekci@mku.edu.tr,

(c) (+90) 3262455313

圆 $(+90) 3262455704$
}

Cemil Kürekci; ORCID no: 0000-0002-6442-2865

Fatih Sakin; ORCID no: 0000-0001-5377-0322

Ali Arslan; ORCID no: 0000-0002-3011-5592

Sait Tan; ORCID no: 0000-0002-8596-9261

Sara Betül Özgen; ORCID no: 0000-0003-0218-7625 
parametreleri ile yapılmıştır. Buna ilaveten Elazı̆̆ ilinde satışa sunulan yirmi adet peynir numunesinde BPA miktarı belirlenmiştir. Bütün metotlar BPA'nın kantitatif analizi için düşük LOD (0.16-0.39 $\mu \mathrm{g} / \mathrm{kg})$ ve LOQ $(0.53-1.30 \mu \mathrm{g} / \mathrm{kg})$ seviyelerinde iyi performans göstermişlerdir. Geri kazanım seviyeleri iki farklı ekleme miktarı $(3-30 \mu \mathrm{g} / \mathrm{kg}$ ) için ortalama \%93.1 ve \%100.8 aralığında hesaplanmıştır. Peynir numunelerinin \%55'inde $0.75 \mu \mathrm{g} / \mathrm{kg}$ ve $8.46 \mu \mathrm{g} / \mathrm{kg}$ miktarları arasında BPA varllğ̣1 bulunmuştur ve günlük alım tahmini (EDI) $0,001 \mu \mathrm{g} / \mathrm{kg}$ vücut ağırlığ1/gün olarak hesaplanmıştır. EDI sonuçlarına göre, peynir tüketimi tek başına BPA için önemli halk sağlığı riski ortaya çıkartmadığı, fakat sonuçlar süt ve süt ürünlerinde BPA'nın düzenli takibinin yapılması gerektiğini göstermiştir.

Anahtar kelimeler: Kat1-faz ekstraksiyonu, Bisfenol A, peynir, HPLC

\section{INTRODUCTION}

Bisphenol A (BPA), 2,2-Bis (4-hydroxyphenyl) propane, is a phenolic compound which is composed of two phenol molecules attached to an acetone molecule (Staples vd., 1998). BPA has been widely utilized in the synthesis of industrial chemical compounds including polycarbonates and epoxy resins to produce a variety of products such as water-pipes, toys, food packages, dental filler and etc. (Welshons vd., 2006). Hence, the requirement of BPA has recently exceeded seven million tons per year, and it is expected that the consumption rate will increase year by year (Jiang vd., 2018).

Once the BPA molecules are polymerized, hydrolysis of ester bonds takes place. In the presence of high temperature, the hydrolysis accelerates either in acidic or basic medium. In other words, when polycarbonate materials or metal cans are heated, BPA occurs owing to hydrolysis of the ester bonds (Welshons vd., 2006). Therefore, numerous studies reported the occurrence of BPA in many products of food contact materials including infant feeding bottles by migrating from polycarbonate (Geens vd., 2012). Inner parts of thin cans are generally covered by epoxy resins to protect the food from any possible corrosion. However, during the synthesis of these epoxy resins, BPA is intensified with epichlorohydrin to form BPA diglycidyl, and at the end of the polymerization, a trace amount of BPA migrates from the resin to the food matrix (Vandenberg vd., 2009). The fact that many factors such as type of foods and its lipid ingredients, $\mathrm{pH}$, temperature and contact time have been shown to affect the release of BPA into the food matrices. Also, ethanol concentration increases the BPA migration into the food media because of the easy polycarbonate depolymerization (Mercogliano and Santonicola, 2018).

Based on the mounting evidence obtained from the recent studies, BPA is reported as endocrinedisrupting chemical (EDC) and such chemicals affect the performance or role of the endocrine system by imitating or obstructing endogenous hormones even at very low doses and this causes excess or low production of hormones (Giulivo vd., 2016). Additionally, it has been proven that BPA could be the cause of many health defects including cancers (especially breast, testicular and ovary), fecundity problems, obesity, and diabetes (Seachrist vd., 2016). For exposure dose of BPA, the safety standard regulated in 1988 for the first time by US Environment Protection Agency established the safety exposure level as $50 \mu \mathrm{g}$ of BPA per kg body weight (BW) per day (USEPA, 1993). In 1996, European Commission classified BPA as an exterior by-product owing to their adverse effects on human health (European Commission, 1996). Later on, the tolerable daily intake (TDI) of BPA was reduced to $4 \mathrm{ng} / \mathrm{g}$ BW/day by the European Food Safety Authority in 2015 (EFSA, 2015).

The serious health effects necessitated the rapid, simple and reliable detection of BPA in various food stuffs, which has been carried out by using instruments like high-performance liquid chromatography (HPLC), gas chromatographymass spectrometry (GC-MS), liquid chromatography-mass spectrometry (LC-MS) and capillary electrophoresis (Ballesteros-Gómez vd., 2009). Before the instrumental analysis, the common sample preparation procedures for extracting BPA out of biological samples consist 
of many steps including but not limited to solvent extraction, purification, intensification and/or separation. The efficiency of extraction is highly variable depending on type of solvents, reagents used, extraction time, and size of samples. For these purposes, there are many extraction procedures described in the literature such as solid-phase extraction (SPE), liquid-liquid extraction (LLE), microwave-assisted extraction (MAE), stir-bar sorptive extraction (SBSE), surfactant-based extraction and ultrasonicassisted extraction (Ballesteros-Gómez vd., 2009). Among these, SPE, based on an analyte separation system subjecting the sample through a solid trap with mobile phase, has been the most widely applied method owing to its high sensitivity, a wide range of applicability, and less solvent consumption (Andrade-Eiroa vd., 2016). It is crucial to select an appropriate absorbent phase for SPE cartridges, which are comprised of different bonding materials. The most known SPE absorbent phases are octadecylsilane (C-18), silica gel, florisil and aminopropyl for the effective extraction (Turner vd., 2009). Although there are several different types of SPE cartridges, C-18 cartridges are principally used for BPA analysis (Grumetto vd., 2008; Kang and Kondo, 2003; Sadeghi vd., 2016).

Recently, there have been numerous SPE studies established and validated for assessing BPA presence and levels in various food matrices (Azzouz vd., 2018). Prior to the SPE device application, sample pretreatment steps such as pre-extraction into solvents, precipitations/filtration of impurities and the $\mathrm{pH}$ adjustments, however, vary widely based on the physicochemical characteristic matrices (Rezaee vd., 2009). Even though there are few reports clearly documenting the presence of BPA in raw milk and dairy products (Grumetto vd., 2013; Mercogliano vd., 2021; Sadeghi vd., 2016; Santonicola vd., 2019), there has been no study attempting to evaluate the effect of different sample pretreatment steps, solvents used in SPE, SPE phase types and as well as different SPE schemes on the extraction efficacy of BPA from cheese products. Hence, this study aimed to compare the extraction efficiency of four different methods (Grumetto vd., 2008; Kang and Kondo, 2003; Sadeghi vd., 2016) on the recovery ratios of BPA in cheese samples by means of validation criteria and practicability (solvent and its quantity, sample volume, total extraction time and SPE cartridge cost). These extraction methods were selected based on different workup procedures, extraction solvents and SPE cartridges [silica-based; Sep-pak (SPK) (Waters, Milford, MA USA), Strata (STR) (Phenomenex, California, USA), Finisterre (FIN) (Spain), Affinimip ${ }^{\circledR}$ Spe BPA Affinisep/Polyintell (AFF) (Paris, France)]. Afterward, twenty cheese samples including Tulum (TC) and white brined pickled (WPC) were analyzed for determination of BPA occurrence.

\section{MATERIALS AND METHODS}

\section{Material}

In order to obtain BPA free cheese for validation, the curd prepared with cow's milk was obtained from a local dairy plant. Physico-chemical characteristics of the curd $(\mathrm{pH}$, dry matter, titratable acidity, fat, and protein) were determined by using methods recommended by AOAC (1995). All measurements and analysis were carried out three times and the mean data was calculated from these replicates. The $\mathrm{pH}$, titratable acidity $(\%)$, dry matter (\%), fat $(\%)$ and protein $(\%)$ of the curd were found to be 5.05 , $0.64,45,28.5$ and 37 , respectively.

\section{Chemicals and reagents}

BPA standard was purchased from Sigma-Aldrich (St. Louis, MO, USA) and methanol, ethanol, acetonitrile, acetone, chloroform, n-hexane were obtained from Merck (Darmstadt, Germany). The chemicals used for the mobile phase were liquid chromatography grade, and others were analytical grade. Additionally, ultra-pure water $\left(\mathrm{UP}-\mathrm{H}_{2} \mathrm{O}\right)$ was obtained from ELGA HPLC ultrapure water system (Ubstadt-Weiher, Germany).

\section{HPLC instrumentation}

Shimadzu-LC-20AD (Shimadzu, Kyoto, Japan) model HPLC system equipped with a multiwavelength fluorescence detector (RF-20AXL, Shimadzu, Kyoto, Japan) was used for BPA analysis. 
GL Sciences Inertsil ODS-3 column $(150 \mathrm{~mm} \times$ $4.6 \mathrm{~mm}, 5 \mu \mathrm{m}$ particle size) (Tokyo, Japan) was used for the separation of BPA and $20 \mu \mathrm{L}$ sample loop was equipped on the manual injection part. A mixture of UP- $\mathrm{H}_{2} \mathrm{O}$ : acetonitrile $(55: 45, \mathrm{v} / \mathrm{v})$ was utilized as mobile phase with a flow rate of $1.0 \mathrm{~mL} \mathrm{~min}{ }^{-1}$. Moreover, the RF detector was set with excitation: $224 \mathrm{~nm}$, emission: $308 \mathrm{~nm}$ and the column temperature was $40{ }^{\circ} \mathrm{C}$. Prior to the analysis, the HPLC column was conditioned with the mobile phase for at least $30 \mathrm{~min}$ to reach stable baseline, and after each analysis, the column was washed from all contaminants with UP- $\mathrm{H}_{2} \mathrm{O}$ : acetonitrile (30:70) for $20 \mathrm{~min}$. Quantification was based on peak area measurement.

\section{Extraction procedures}

Method I using Affinisep SPE cartridge

Extraction procedure using Affinisep SPE cartridges was followed as outlined in the supplier's application guidelines. Cheese sample $(3.0 \mathrm{~g})$ was mixed with $30 \mathrm{~mL}$ water $\left(\sim 50^{\circ} \mathrm{C}\right)$. Then, $20 \mathrm{~mL}$ of this mixture was combined with $20 \mathrm{ml}$ acetonitrile and centrifuged at $4000 \mathrm{rpm}$ for $10 \mathrm{~min}$. The supernatant was collected and filtered through filter paper (No.4 Whatman). This extract was diluted 1:1 (v:v) with $\mathrm{UP}-\mathrm{H}_{2} \mathrm{O}$ to form the adding solution. The cartridge was conditioned with $3 \mathrm{~mL}$ methanol: acetic acid (98:2, v:v), $3 \mathrm{ml}$ acetonitrile and $3 \mathrm{~mL} \mathrm{UP}-\mathrm{H}_{2} \mathrm{O}$, respectively. Then, $40 \mathrm{~mL}$ of extract $(\mathrm{pH}$ adjusted to 5-6) was added into the column that was washed with $9 \mathrm{~mL}$ UP- $\mathrm{H}_{2} \mathrm{O}$ and $6 \mathrm{ml}$ UP- $\mathrm{H}_{2} \mathrm{O}$ : acetonitrile (6:4, v:v). After drying the column about $30 \mathrm{~s}$, elution was done with $3 \mathrm{~mL}$ methanol. The elution fraction was then evaporated with gas nitrogen and then dissolved in the $2 \mathrm{~mL}$ mobile phase [UP- $\mathrm{H}_{2} \mathrm{O}$ : acetonitrile $\left.(55: 45, \mathrm{v}: \mathrm{v})\right]$ for HPLC analysis.

\section{Method II using C18 Strata E SPE cartridge}

The extraction procedure was carried out according to Grumetto vd. (2008) $150 \mathrm{~mL}$ acetonitrile and $20.0 \mathrm{~g}$ of cheese sample were mixed and homogenized in Waring blender (New Hartford, CT, USA) for $30 \mathrm{~s}$ at high speed. Then, the mixture was filtered through a filter paper (Whatman size 4). For separation of fat in the matrix, the acetonitrile layer was mixed with $\mathrm{n}$-hexane and shaken strongly for $1 \mathrm{~min}$. After separation, the acetonitrile layer was taken into a rounded-bottom flask and evaporated by a rotary evaporator (IKA, Brandenburg, Germany). The residue remaining in the flask was solved in $6 \mathrm{ml}$ of $\mathrm{UP}-\mathrm{H}_{2} \mathrm{O}$ : acetonitrile $(9: 1, \mathrm{v}: \mathrm{v})$.

For cleanup of the extract, the cartridge was conditioned with $5 \mathrm{ml}$ acetonitrile, followed by 5 $\mathrm{mL}$ UP- $\mathrm{H}_{2} \mathrm{O}$ : acetonitrile (9:1, v:v). Then, $6 \mathrm{~mL}$ of the extract was passed through the cartridge which was subsequently cleaned with $20 \mathrm{~mL}$ mixture of $\mathrm{UP}-\mathrm{H}_{2} \mathrm{O}$ : acetonitrile (16:4, v:v). Finally, the cartridges were eluted with $5 \mathrm{~mL}$ acetonitrile two times. After the acetonitrile phases evaporation, the extract was dissolved with $10 \mathrm{~mL}$ UP- $\mathrm{H}_{2} \mathrm{O}$ : acetonitrile $(9: 1, \mathrm{v}: \mathrm{v})$ to inject to HPLC.

\section{Method III using Finisterre cartridge}

This extraction method was carried out according to Sadeghi vd. (2016) with minor modifications (Rezaee vd., 2009). $5 \mathrm{~mL}$ of ethanol:UP- $\mathrm{H}_{2} \mathrm{O}$ (1:1, $\mathrm{v}: \mathrm{v})$ was added to $1.0 \mathrm{~g}$ cheese sample and the solution was mixed for $2 \mathrm{~min}$ in the ultrasonic chamber. Then, the mixture was centrifuged at $5000 \mathrm{rpm}$ for $40 \mathrm{~min}$ and filtered through the filter paper (No.4 Whatman). Then, the final volume was completed to $100 \mathrm{~mL}$ with UP- $\mathrm{H}_{2} \mathrm{O}$ and $\mathrm{pH}$ of the mixture was adjusted to 6-7 by $\mathrm{NaOH}(10 \%)$. The final mixture was applied to the SPE cartridge which was previously conditioned with $4 \mathrm{~mL}$ acetone and $4 \mathrm{ml} \mathrm{UP}$ $\mathrm{H}_{2} \mathrm{O}$. For the elution step, $2 \mathrm{~mL}$ acetone including chloroform $(142 \mu \mathrm{L})$ as a dispersive solvent was passed slowly and collected in a clean tube. Then, the cloudy mixture was centrifuged at $6000 \mathrm{rpm}$ for $5 \mathrm{~min}$. After centrifugation, the sedimented phase was transferred into another tube and evaporated in a water bath at $50^{\circ} \mathrm{C}$. The residue was dissolved in $1 \mathrm{~mL}$ mobile phase, and subsequently analyzed with HPLC.

\section{Method IV using Sep-Pak cartridge}

The procedure described by Kang and Kondo (2003) was applied with Sep-Pak cartridge extraction. Homogenized cheese sample $(5.0 \mathrm{~g}$ ) was mixed with $30 \mathrm{~mL}$ acetonitrile and $30 \mathrm{~mL}$ hexane in a blender (New Hartford, CT, USA). 
The mixture was taken into the separatory funnel for about $10 \mathrm{~min}$. The acetonitrile layer was filtered (No.4 Whatman) and evaporated with the rotary evaporator (IKA, Brandenburg, Germany). Then, the residue was dissolved with $6.0 \mathrm{~mL}$ UP$\mathrm{H}_{2} \mathrm{O}$ and passed through the cartridges, which were conditioned before with $10 \mathrm{~mL}$ methanol

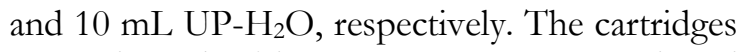
were cleaned with $20 \mathrm{~mL}$ UP- $\mathrm{H}_{2} \mathrm{O}$ : methanol (19:1, v:v) and the analyte was eluted with $5 \mathrm{~mL}$ methanol into the vials. Finally, the methanol was blown dry using a stream of nitrogen gas and the residue was reconstituted with $5 \mathrm{ml}$ mobile phase, then analyzed by HPLC.

\section{Method validation}

Validation of the HPLC method included linearity, sensitivity and precision. BPA stock standard solution was prepared in methanol at a concentration of $100 \mathrm{ng} / \mathrm{g}$. Then, the working solutions were diluted freshly from the stock solution with ultra-pure water. The calibration curve was generated by using 0.5, 1.0, 2.5, 5.0 and $10.0 \mu \mathrm{g} / \mathrm{kg}$. Each concentration was injected to HPLC three times and the obtained peak areas were used for the calibration curve.

While limit of detection (LOD) was determined by the lowest concentration of standard equivalent to signal-to-noise ratio of three, the limit of quantitation (LOQ) was calculated from the lowest concentration of the standard that provided signals equal to 10 times the noise signal of analysis.

The precision was the scaling of results to compare the results with each other. In order to calculate precision, repeatability and within-lab reproducibility was carried out. Repeatability was determined by analyzing the six replicates of spiked blank samples with selected low $(3 \mu \mathrm{g} / \mathrm{kg})$ and high $(30 \mu \mathrm{g} / \mathrm{kg})$ levels in the same day. Within-lab reproducibility was done by two different analysts in three different days with low and high-level spikes. Recovery was calculated according to repeatability results.

\section{Analysis of market cheese samples}

Twenty cheese samples (TC; $n=10$; and WPC; $\mathrm{n}=10$ ) were randomly purchased from local markets in Elazığ province, Turkey. The samples were taken into the glass jars and stored at $-20^{\circ} \mathrm{C}$ until the extraction process. Samples were treated using Method IV with Sep-Pak cartridge. The experiments were performed in triplicate and data processing was performed using SPSS software (SPSS, Chicago, USA).

\section{Exposure and hazard assessment}

In order to determine the consumer's BPA exposure, the estimated daily intake (EDI) value was calculated using the following formula adapted from Bemrah vd., (2014):

\section{$E D I(\mu g / k g B W)=\frac{\text { the mean concentration of BPA }(\mu \mathrm{g} / \mathrm{kg}) \times \text { the daily mean consumption of cheese per person }(23,3 \mathrm{~g})}{\text { body weight }(65 \mathrm{~kg})}$}

BPA levels lower than LOQ $(0.75 \mu \mathrm{g} / \mathrm{kg})$ were censored and the mean concentration of BPA was calculated on the basis of values over the LOQ level, which was obtained in $55 \%$ of cheese analyzed. The estimated annual consumption of cheese is $8.5 \mathrm{~kg}$ per person (Hayaloğlu and Özer, 2011), from which the daily cheese consumption per person was calculated.

\section{RESULTS AND DISCUSSION}

In the present experiment, we compared the performance of four different methods to obtain BPA from cheese samples. The validation criteria, which have to be met before applying any procedure to quantify a compound from food matrices, were first examined and the validation results of the extraction methods are provided in Table 1. As can be seen, the average recoveries ranged from $97.6 \%$ to $102.3 \%$ and from $88.7 \%$ to $99.7 \%$ at $3 \mu \mathrm{g} / \mathrm{kg}$ and $30 \mu \mathrm{g} / \mathrm{kg}$, respectively. The highest rate was obtained in method I using affinisep cartridge and the lowest rate was obtained in method IV using sep pak cartridge. These results are much higher than the requirements established by the European Commission (EC, 2002), indicating the high extraction capacity of all methods with high sensitivity. Other studies also noted high recovery rates for skimmed milk (97.6\%) using the method 
IV with Sep-Pak cartridge (Kang and Kondo, 2003) and for canned peeled tomatoes at the recovery rate of $94.55 \%$ using method II+Strata cartridge (Grumetto vd., 2008).

Table 1. Validation results of different SPE methods

\begin{tabular}{|c|c|c|c|c|c|c|c|c|c|c|c|c|c|}
\hline \multirow{3}{*}{ Metods } & \multirow{3}{*}{\multicolumn{2}{|c|}{$\begin{array}{l}\text { LOD- } \\
\text { LOQ } \\
(\mu \mathrm{g} / \mathrm{kg})\end{array}$}} & \multirow{3}{*}{$\begin{array}{l}\text { Calibration } \\
\text { curve }\end{array}$} & \multicolumn{7}{|c|}{ Precision } & \multirow{3}{*}{$\begin{array}{c}\text { Measurement } \\
\text { uncertainty } \\
\text { (expanded } \\
\text { measurement } \\
\text { uncertainty) }\end{array}$} & \multirow{3}{*}{$\begin{array}{l}\text { Extraction } \\
\text { time (min) }\end{array}$} & \multirow{3}{*}{ Cost } \\
\hline & & & & \multicolumn{5}{|c|}{ Recovery \% } & \multicolumn{2}{|c|}{$\operatorname{RSD} \%{ }^{a}$} & & & \\
\hline & & & & $\begin{array}{l}\text { Intra- } \\
\text { day } \\
\text { RSD } \%\end{array}$ & $\begin{array}{l}\text { Inter- } \\
\text { day } \\
\text { RSD } \%\end{array}$ & $\begin{array}{c}3 \\
\mu \mathrm{g} / \mathrm{kg}\end{array}$ & $\begin{array}{c}30 \\
\mu \mathrm{g} / \mathrm{kg}\end{array}$ & $\begin{array}{l}\text { Mean } \\
\text { recovery }\end{array}$ & $\begin{array}{l}\text { Low } \\
\text { level }\end{array}$ & $\begin{array}{l}\text { High } \\
\text { level }\end{array}$ & & & \\
\hline $\begin{array}{l}\text { Metod } \\
\text { I }\end{array}$ & $\begin{array}{l}0.39 \\
1.30\end{array}$ & - & $\begin{array}{l}\text { Linearity range } \\
(\mu \mathrm{g} / \mathrm{kg})=0.5-\end{array}$ & 8.8 & 4.2 & 102 & 99.7 & 100.8 & 7.8 & 10.7 & 0.70 & 30 & 21 \\
\hline $\begin{array}{l}\text { Metod } \\
\text { II }\end{array}$ & $\begin{array}{l}0.24 \\
0.79\end{array}$ & - & $\mathrm{R}^{2}=0.998$ & 4.7 & 7.1 & 102.3 & 92.7 & 97.5 & 4.5 & 5.9 & 0.55 & 60 & 10 \\
\hline $\begin{array}{l}\text { Metod } \\
\text { III }\end{array}$ & $\begin{array}{l}0.16 \\
0.53\end{array}$ & - & $\begin{array}{l}\text { BPA retention } \\
\text { time }=6.2 \mathrm{~min}\end{array}$ & 10.6 & 7.2 & 97.6 & 88.7 & 93.1 & 6.9 & 11.7 & 1.24 & 60 & 4 \\
\hline $\begin{array}{l}\text { Metod } \\
\text { IV }\end{array}$ & $\begin{array}{l}0.23 \\
0.75\end{array}$ & - & & 7.6 & 7.1 & 100.2 & 94.2 & 94.2 & 6.5 & 7.3 & 1.01 & 40 & 7 \\
\hline
\end{tabular}

a RSD $=$ standard deviation / mean $* 100 \%$

b Expanded Measurement Uncertainty $=$ Combined Standard Uncertainty x 2

${ }^{c}$ Cost per unite cartridge (\$USA) in 2018.

The precision of the methods, expressed by relative standard deviation as a percentage (RSD\%), was estimated by results of spiked samples in intra and inter days. The precision responses were calculated between $4.7-10.6 \%$ and $4.2-7.2 \%$ for the inter-day and intra-day precision tests, respectively. The linear response of BPA in the concentration range of 0.5 to $10.0 \mu \mathrm{g} / \mathrm{kg}$ without matrix was obtained and the correlation coefficient was found to be 0.998 . Figure 1 shows the typical HPLC chromatograms of the BPA from cheese samples before and after being spiked ( 3 and $30 \mu \mathrm{g} / \mathrm{kg}$ ).

LODs in the range of $0.16-0.39 \mu \mathrm{g} / \mathrm{kg}$ and LOQs between 0.53 and $1.30 \mu \mathrm{g} / \mathrm{kg}$ were obtained in this study (Table 1). The lowest LOD and LOQ were recorded for the method III $(0.16 \mu \mathrm{g} / \mathrm{kg}$ and 0.53 $\mu \mathrm{g} / \mathrm{kg}$, respectively), and the trend was as follows: method III $<$ method IV $<$ method II $<$ method I. The values were found to be comparable to those reported by Alnaimat vd., (2019) for 0,72 and 0,24 $\mu \mathrm{g} / \mathrm{L}$, LOD and LOQ, respectively, using LCESI-MS method. Yang vd., (2014) also noted 0,12 $\mathrm{ng} / \mathrm{g}$ LOQ for canned fish using Affinisep cartridge. Yet, the limits of quantification and detection are slightly lower than the values reported by Sun vd., (2006) and much better than those obtained by Li vd., (2014) (LOD; $3 \mu \mathrm{g} / \mathrm{L}$ ) for BPA determination in drinks using DSMIP. Sadeghi vd., (2016) combined SPE with dispersive liquid-liquid microextraction (SPE-
DLLME-SFO) sample preparation techniques and applied it to the determination of BPA in different food matrices followed by subsequent analysis by HPLC. Authors achieved very low LOD value $(0,002 \mathrm{ng} / \mathrm{g})$ with satisfactory recoveries. Loh vd., (2017) also used this technique with slight modification to extract BPA from water and beverage samples and obtained LOD value of $0.02-0.03 \mu \mathrm{g} / \mathrm{L}$, which is even 10 times lower than that obtained in our experiment. However, SPE-DLLME-SFO method reported by Sadeghi vd., (2016) requires the use of 1undecanol as extractor solvent, which was found to be making assignment of BPA harder because of the interfering peak on the blank sample chromatogram in preliminary experiment (data not given). A similar observation has also been noted by Nascimento and Rocha (2018), who reported 1-undecanol as unsuitable extractor solvent which presented blank values as high as the analytical response of BPA $(100 \mu \mathrm{g} / \mathrm{L})$ when ethanol was used as eluent solvent on the extraction and analysis of PBA using LLMEHPLC with fluorimetric detection. The other disadvantage of using 1-undecanol is its relatively expensive cost, which also limits its use as extraction solvent. So that, some modifications described by Rezaee vd., (2009) were introduced into the method described by Sadeghi vd., (2016) in order to adapt it to the determination of BPA in HPLC system. 


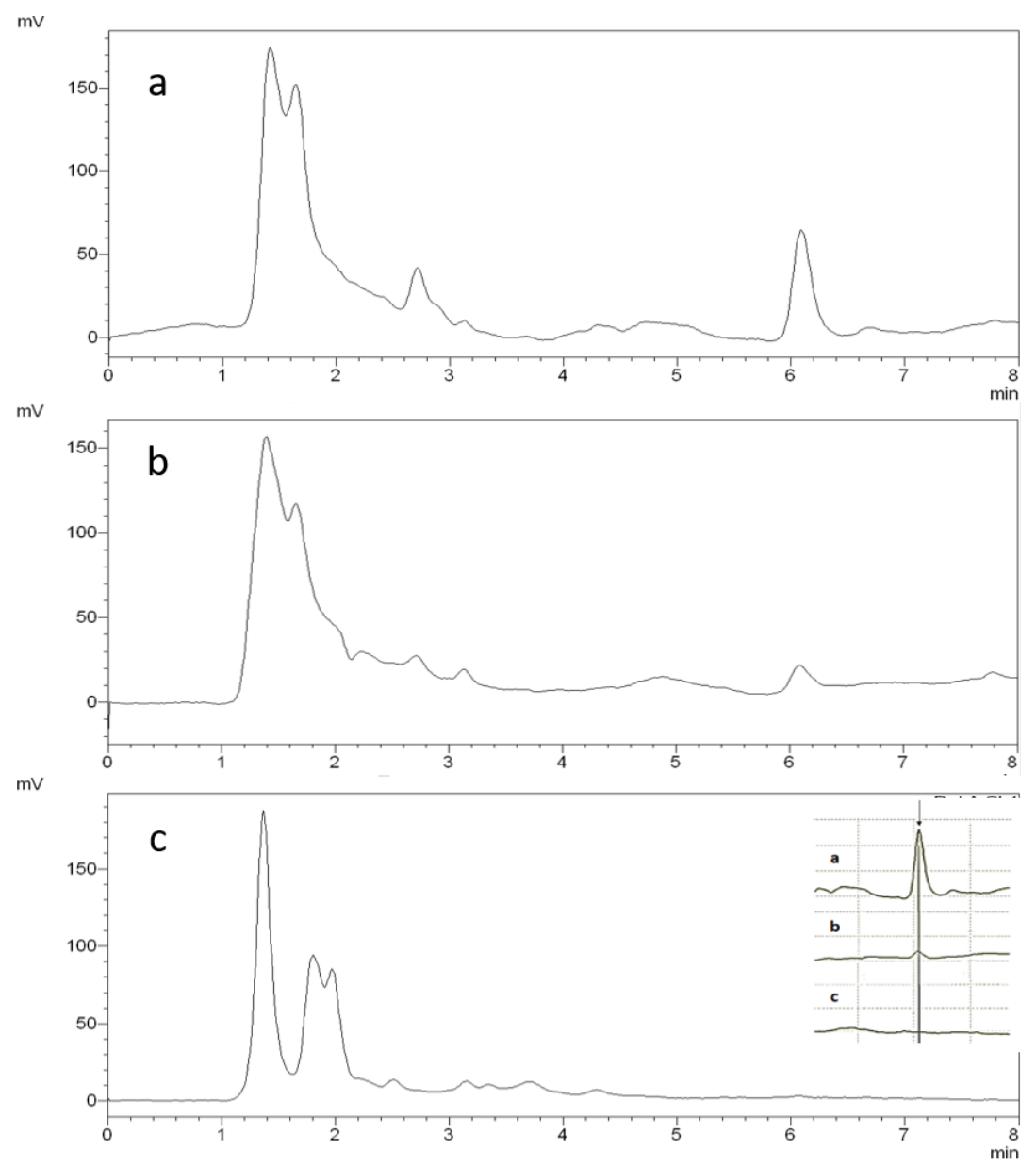

Figure 1. The chromatograms of cheese samples spiked with (a) $30 \mu \mathrm{g} / \mathrm{kg}$ and (b) $3 \mu \mathrm{g} / \mathrm{kg}$ of BPA per $\mathrm{kg}$ and (c) non-spiked. Peak identification: (1) PBA.

Table 2. BPA occurrence in cheeses

\begin{tabular}{lcccc}
\hline \multirow{2}{*}{ Contaminant } & \multicolumn{4}{c}{ Residue content n $(\%)$} \\
\cline { 2 - 5 } & $<$ LOD & LOD - LOQ & LOQ $-4(\mu \mathrm{g} / \mathrm{kg})$ & $4(\mu \mathrm{g} / \mathrm{kg})<$ \\
\hline BPA & $5(25 \%)$ & $4(20 \%)$ & $8(40 \%)$ & $3(15 \%)$ \\
\hline
\end{tabular}

As previously indicated, effective extraction of BPA from food matrices varies depending on a variety of factors including the right concentration of the disperser solvent (Rezaee vd., 2006). As the sample size increases, the amount of solvent required for extraction can be enormous and this can increase the treatment costs, occupational risks as well as environmentally dangerous waste. To overcome these drawbacks, various microextraction modified techniques such as SPME (solventless format) and DLLME (dispersive concept) are developed. However, these techniques have some disadvantages such as expensive SPME fibers, fragile adsorbent layers, low enrichment factor, etc. (Cunha vd., 2012; Vera-Avila vd., 2013). In the current experiment, the methods used three different disperser solvents; namely, acetonitrile, ethanol, and acetonitrile+hexane, all of which resulted in efficient recovery from cheese, fatty food matrice. Method III required a small sample size (as little as one gr) with minimal use of organic solvent ( $5 \mathrm{~mL}$ ethanol). However, method II involved adding a large amount of solvent (150 
$\mathrm{mL}$ of acetonitrile) to a considerably higher amount of sample (20 gr), which can bring environmental burden.

SPE-based pretreatment methods, as being multistep process, require long treatment time and some sophisticated equipment including cartridges, which has been shown to increase process cost as well as impacting the extraction efficiency (Azzouz vd., 2018). Regarding the extraction time, method $I$ is the fastest of the four methods, requiring about $30 \mathrm{~min}$ (Table 1). However, its cartridge is the most expensive in cost, even though this method can be efficient and practical one for larger number of laboratory analyses. In fact, method III was found to require the cheapest cartridge. However, the disadvantage of using method II and III is the significant working up time requirement (almost one h). On the other hand, method IV was found to be rapid enough to be used for the large-scale monitoring with considerably less equipment cost. In view of the satisfactory results, this method appeared to be practical for the analysis of BPA in real cheese samples sold in the market.

BPA was detected in $55 \%$ of the analyzed cheese samples using the selected extraction method (method IV), the levels ranging from LOQ $(0.75$ $\mu \mathrm{g} / \mathrm{kg}$ ) to $8.46 \mu \mathrm{g} / \mathrm{kg}$, with the mean concentration of $3.01 \mu \mathrm{g} / \mathrm{kg}$. The result of this study is comparable to the levels reported previously in other countries. For example, Cao vd., (2011) reported BPA concentration of 0.68$2.24 \mu \mathrm{g} / \mathrm{kg}$ in cheese samples. In addition, a French study by Bemrah vd., (2014) reported similar BPA concentration in the range of 0.105$6.103 \mu \mathrm{g} / \mathrm{kg}$ (mean value of $1.017 \mu \mathrm{g} / \mathrm{kg}$ ) in cheese. The presence of BPA in dairy products is not surprising since previous studies indicated the presence of BPA in raw milk samples at 1.3-2.4 $\mathrm{ng} / \mathrm{g}$ in Iran (Sadeghi vd., 2016) and 0.035-2.776 $\mu \mathrm{g} / \mathrm{L}$ in Italy (Santonicola vd., 2019) and even at levels up to $521.0 \mu \mathrm{g} / \mathrm{L}$ in commercial milk samples (Grumetto vd., 2013). For comparison purposes, higher concentration of BPA has been found in other foods of animal origin including in egg (133 ng/g) (Liao and Kannan, 2013) and not canned meat (13 $\mu \mathrm{g} / \mathrm{kg}$ ) (Bemrah vd., 2014), yet somewhat lower in quantified in meat $(0.48$ $\mu \mathrm{g} / \mathrm{kg})$, poultry liver pate $(0.48 \mu \mathrm{g} / \mathrm{kg})$ and butter (0.56 $\mu \mathrm{g} / \mathrm{kg}$ ) (Wlodarczyk, 2015). Noticeable differences in the concentration of BPA were observed among cheese types and samples in the current study. It is a well-known fact that the presence and level of BPA in food matrices are influenced by a variety of factors such as heat treatment and $\mathrm{pH}$ levels, and are also highly associated with the migration from their packing during the ripening process or/and storage period.

Dairy products, especially cheese, take an important place in the human diet due to the precious nutrient contents. However, the presence of BPA in these products may lead to significant negative impact on human health. In order to estimate risks from the dietary intake of BPA through cheese consumption, Santonicola vd., (2019) determined BPA level in raw milk samples and subsequently estimated likely quantitative occurrence in cheese. These authors have shown high dietary intake of BPA (the range of $0.0025-0.2235 \mu \mathrm{g} / \mathrm{kg}$ of $\mathrm{BW}$ per day) for all age groups in Italian population. According to Santanicola vd., (2019), BPA in raw milk with daily intakes of $0.001-0.022 \mu \mathrm{g} / \mathrm{kg}$ of BW per day poses risk to humans. In contrast to this study, much lower daily exposure $(0.001 \mu \mathrm{g} / \mathrm{kg}$ of BW per day) is predicted for adult population in Turkey. Based on the average daily intake, which is much lower than the maximum allowed guideline value of $4 \mathrm{ng} / \mathrm{g} \mathrm{BW} /$ day established by EFSA (2015), cheese consumption itself is of much lesser significance for the general population in Turkey. This discrepancy could be partially explained by the cheese consumption habits between Turkey (23.3 g/day per person) and Italy $(61,8 \mathrm{~g} /$ day for adult population) (Santanicola vd., 2019). It is still worth highlighting that dairy commodities, especially cheese preserved in plastic containers, could be an important contributor to the total dietary intake of BPA. For example, a risk estimation by Bemrah vd., (2014), based on their BPA contamination levels in a variety of foods in France, reported the mean daily intake of $0.038-0.040 \mu \mathrm{g} / \mathrm{kg}$ of BW for adults (>18 years old). EFSA (2015) has estimated 
higher amount of BPA exposure through contaminated food consumption for different age groups of the human population ranging from 0.388 to $0.857 \mu \mathrm{g} / \mathrm{kg}$ of $\mathrm{BW}$ per day.

\section{CONCLUSION}

Based on the results, all methods used in this work were found to be reliable from the viewpoint of validation performance (good recoveries, precision and etc.) for the extraction of BPA from cheese samples. Therefore, these four methods tested can be recommended for the routine analysis of BPA in dairy products, even though they suffer from some limitations. These methods are limited to specific cartridge, which basically increases the cost. To sum up, method IV was preferable, because it not only provided costeffective and convenient procedure, but also comparably short processing time. Using the selected method, eleven cheese samples $(55 \%)$ had BPA, but the resultant daily exposure level through cheese consumption was found to be much less than the maximum permissible intake. Overall, the current study documented the presence of PBA in cheese samples and consequently emphasized the need for further health implications with different exposure scenarios in Turkey.

\section{ACKNOWLEDGEMENTS}

We would like to thank Hatay Mustafa Kemal University for English editing service.

\section{CONFLICT OF INTEREST}

The authors declare no conflict of interest.

\section{AUTHOR CONTRIBUTION}

C.K. and F.S. designed and supervised the study. S.T. and S.B.Ö. performed the validation and experiments. C.K. and A.A. analyzed the data. C.K. prepared the manuscript. A.A. and F.S. edited the manuscript. All of the authors have read the final version of the manuscript and approved its submission for publication.

\section{FUNDING}

This work did not get any financial support.

\section{REFERENCES}

Alnaimat AS, Barciela-Alonso MC, BermejoBarrera P. (2019). Determination of bisphenol A in tea samples by solid phase extraction andliquid chromatography coupled to mass spectrometry. Microchem J, 147, 598-604.

Andrade-Eiroa A, Canle M, Leroy-Cancellieri V, Cerdà V. (2016). Solid-phase extraction of organic compounds: A critical review (Part I). Trends Analyt Chem, 80: 641-654.

Azzouz A, Kailasa SK, Lee SS, Rascón AJ, Ballesteros E, Zhang M, Kim K-H. (2018). Review of nanomaterials as sorbents in solidphase extraction for environmental samples. Trends Analyt Chem, 108: 347-369.

Ballesteros-Gómez A, Soledad R, Dolores PB. (2009). Analytical methods for the determination of bisphenol A in food. J Chromatogr A 1216: 449-469.

Bemrah N, Jean J, Rivière G, Sanaa M, Leconte S, Bachelot M., Deceuninck Y, Le Bizec B, Dauchy X, Roudot A-C, Camel V, Grob K, Feidt C, Picard-Hagen N, Badot P-M, Foures F, Leblanc J-C. (2014). Assessment of dietary exposure to bisphenol A in the French population with a special focus on risk characterization for pregnant French women. Food Chem Toxicol, 72: 90-97.

Cao XL, Perez-Locas C, Dufresne G, Clement G, Popovic S, Beraldin F, Dabeka RW, Feeley M. (2011). Concentrations of bisphenol A in the composite food samples from the 2008 Canadian total diet study in Quebec City and dietary intake estimates. Food Addit Contam, 28: 791-798.

Cunha S, Cunha C, Ferreira A, Fernandes J. (2012). Determination of bisphenol A and bisphenol B in canned seafood combining QuEChERS extraction with dispersive liquidliquid microextraction followed by gas chromatography-mass spectrometry. Anal Bioanal Chem, 404: 2453-2463.

EFSA (2015). Scientific Opinion on the risks to public health related to the presence of bisphenol A (BPA) in foodstuffs: executive summary. EFSAJ, 13: 3978. 
European Commission 2002/657/EC. (2002). Commission Decision of 12 August 2002 implementing Council Directive 96/23/EC concerning the performance of analytical methods and the interpretation of results, Off $J$ Eur Commun, L221: 8 - 36.

European Commission. (1996). European workshop on the impact of endocrine disruptors on human health and wildlife. Report of Proceedings from a Workshop held in Weybridge, UK, December 2-4, 1996. Report reference EUR 17549, European Commission, DG XII, Brussels, Belgium.

Geens T, Aerts D, Berthot C, Bourguignon JP, Goeyens L, Lecomte P, Maghuin-Rogister G, Pironnet A-M, Pussemier L, Scippo M-L, Van Loco J, Covaci A. (2012). A review of dietary and non-dietary exposure to bisphenol-A. Food Chem Toxicol, 50: 3725-3740.

Giulivo M, de Alda ML, Capri E, Barceló D. (2016). Human exposure to endocrine disrupting compounds: Their role in reproductive systems, metabolic syndrome and breast cancer. A review. Environ Res 151, 251-264.

Grumetto L, Gennari O, Montesano D, Ferracane R, Ritieni A, Albrizio S, Barbato F. (2013). Determination of five bisphenols in commercial milk samples by liquid chromatography coupled to fluorescence detection. J Food Protect, 76: 1590-1596.

Grumetto L, Montesano D, Seccia S, Albrizio S, Barbato F. (2008). Determination of bisphenol A and bisphenol $\mathrm{B}$ residues in canned peeled tomatoes by reversed-phase liquid chromatography. J Agric Food Chem, 56, 1063310637.

Hayaloğlu AA, Özer B. (2011). Giriş. In A. A. Hayaloğlu and B. Özer (Eds) Peynir Biliminin Temelleri (pp. 1-8). İzmir, Sidas.

Jiang D, Chen WQ, Zeng X, Tang L. (2018). Dynamic Stocks and Flows Analysis of Bisphenol A (BPA) in China: 2000-2014. Environ Sci Technol, 52: 3706-3715.

Kang JH, Kondo F. (2003). Determination of bisphenol $\mathrm{A}$ in milk and dairy products by high- performance liquid chromatography with fluorescence detection. J Food Protect, 66, 14391443.

Li J, Zhou H, Liu YX, Yan XY, Xu YP, Liu SM. (2014). Solid-phase extraction for selective determination of bisphenol $\mathrm{A}$ in drinks and fruits by dummy surface molecularly imprinted polymer with direct synthetic method. Food Addit Contam, 31: 1139-1146.

Liao C, Kannan K. (2013). Concentrations and profiles of bisphenol $A$ and other bisphenolanalogues in foodstuffs from the United States and their implications for human exposure. J Agr Food Chem, 61: 4655-4662.

Loh SH, Ong ST, Ngu ML, Ariffin MM. (2017). Rapid extraction of bisphenol A by dispersive liquid-liquid microextraction based on solidification of floating organic. Sains Malays, 46: 615-621.

Mercogliano R, Santonicola S. (2018). Investigation on bisphenol A levels in human milk and dairy supply chain: A review. Food Chem Toxicol, 114: 98-117.

Mercogliano R, Santonicola S, Albrizio S, Ferrante MC. (2021). Occurrence of bisphenol A in the milk chain: A monitoring model for risk assessment at a dairy company. J Dairy Sci, 104, 5125-5132.

Nascimento CF, Rocha FRP. (2018). Spectrofluorimetric determination of bisphenol A in tap waters byexploiting liquid-liquid microextraction in a sequential injection system. Microchem J, 137: 429-434.

Rezaee M, Yamini Y, Shariati S, Esrafili A, Shamsipur M. (2009). Dispersive liquid-liquid microextraction combined with highperformance liquid chromatography-UV detection as a very simple, rapid and sensitive method for the determination of bisphenol $\mathrm{A}$ in water samples. J Chromatogr A, 1216: 1511-1514.

Sadeghi M, Nematifar Z, Fattahi N, Pirsaheb M, Shamsipur M. (2016). Determination of bisphenol A in food and environmental samples using combined solid-phase extraction-dispersive liquid-liquid microextraction with solidification 
of floating organic drop followed by HPLC. Food Anal Methods, 9: 1814-1824.

Santonicola S, Ferrante MC, Murru N, Gallo P, Mercogliano R. (2019). Bisphenol A in cow milk and dietary exposure at the farm level. J Dairy Sci, 102: 1007-1013.

Seachrist DD, Bonk KW, Ho SM, Prins GS, Soto AM, Keri RA. (2016). A review of the carcinogenic potential of bisphenol A. Reprod Toxicol, 59: 167-182.

Staples CA, Dome PB, Klecka GM, Oblock ST, Harris LR. (1998). A review of the environmental fate, effects, and exposures of bisphenol A. Chemosphere, 36: 2149-2173

Sun C, Leong LP, Barlow PJ, Chan SH, Bloodworth BC. (2006). Single laboratory validation of a method for the determination of bisphenol A, bisphenol A diglycidyl ether and its derivatives in canned foods by reversed-phase liquid chromatography. J Chromatogr A, 1129: 145148.

Turner NW, Subrahmanyam S, Piletsky SA. (2009). Analytical methods for determination of mycotoxins: A review. Analytica Chim Acta, 632: 168-180.

US Environmental Protection Agency (USEPA). (1993). Bisphenol A. (CASRN 80-05-7), integrated risk information system (IRIS). USEPA, Washington, DC. Available from: http://www.epa.gov/iriswebp/iris/subst/0356.h tm.

Vandenberg LN, Maffini MV, Sonnenschein C, Rubin BS, Soto AM. (2009). Bisphenol-A and the great divide: A review of controversies in the field of endocrine disruption. Endocr Rev, 30: 75-95.

Vera-Avila LE, Rojo-Portillo T, CovarrubiasHerrera R, Pena-Alvarez A. (2013). Capabilities and limitations of dispersive liquidliquidmicroextraction with solidification of floating organic drop for theextraction of organic pollutants from water samples. Anal Chim Acta, 805: 60-69.

Welshons WV, Susan CN, vom Saal FS. (2006). Large effects from small exposures. III. Endocrine mechanisms mediating effects of bisphenol A at levels of human exposure. Endocrinology, 147: 56-69.

Wlodarczyk E. (2015). Occurrence of bisphenol $\mathrm{A}$ and its effects on the human body. Arch Physiother Glob Res, 19: 13-26.

Yang Y, Yu J, Yin J, Shao B, Zhang J. (2014). Molecularly imprinted solid-phase extraction for selective extraction of bisphenol analogues in beverages and canned food. J Agric Food Chem, 62: 11130-11137. 